Metallophysics and Advanced Technologies

Металофіз. новітні технол.

Metallofiz. Noveishie Tekhnol.

2021 , vol. 43 , No. 7 , pp. 959-969

https://doi.org/10.15407/mfint.43.07.0959

Reprints available directly from the publisher
(C) 2021 G. V. Kurdyumov Institute for Metal Physics, National Academy of Sciences of Ukraine Published by license under

the G. V. Kurdyumov Institute for Metal PhysicsN.A.S. of Ukraine Publishers imprint. Printed in Ukraine.

PACS numbers: 02.70.-c, 06.30.Bp, 07.05.Tp, 81.40.Jj, 81.40.Lm, 81.40.Vw

\title{
Stress State of 6063 Cold-Formed Aluminium Alloy Workpieces in a Closed Die
}

\author{
Zh. Ashkeyev and M. Abishkenov \\ Karaganda Industrial University, \\ 30 Republic Ave., \\ 101400 Temirtau, Kazakhstan
}

The article presents the results of stress state analysis for workpieces from aluminium alloy 6063 cold-formed in a closed die. Mathematical methods of computer modelling (finite element method) and slip lines (slip-line field method) are used for the analysis. The experimental procedure for repeated cold deformation in a closed matrix (in several passes and/or cycles), the mechanisms of grain grinding and material hardening under the influence of grain-dislocation factors are described. The results of the stress state study of the material during cold deformation (at room temperature) show that the volume of the workpiece is mainly compressive stresses, the values of which are in the range from $-273 \mathrm{MPa}$ to $-533 \mathrm{MPa}$. As found, due to the hydrostatic stress from the side of the punches and the side walls of the semi-dies, the workpiece is subjected to triaxial compression, which makes it possible to obtain volumetric spherical workpieces with ultrafine-grained nanostructure in a closed die with minimal processing cycles.

Key words: slip-line field method, finite element method, stress state, closed die, compressive stresses, triaxial compression.

У роботі представлено результати аналізу напруженого стану заготівок 3 алюмінієвого стопу 6063, холоднодеформованих у закритій матриці. Для аналізу використано методи комп'ютерного моделювання та ліній ковзання. Дано опис експериментальної процедури для багаторазового холодного деформування у закритій матриці (за кілька проходів та/або циклів), механізмів подрібнення зерен і зміцнення матеріалу під впливом зерен-дислокаційних факторів. Результати дослідження напруженого ста-

Corresponding author: Maksat Abishkenov

E-mail:maksatabiskenov@gmail.com

Citation: Zh. Ashkeyev and M. Abishkenov, Stress State of 6063 Cold-Formed Aluminium Alloy Workpieces in a Closed Die, Metallofiz. Noveishie Tekhnol., 43, No. 7: 959-969 (2021), DOI: 10.15407/mfint.43.07.0959. 
ну матеріалу у разі деформації у холодному стані (за кімнатної температури) показали, що в об'ємі заготівки діють переважно стискувальні напруження, значення яких знаходяться в інтервалі від -273 МПа до -533 МПа. Виявлено, що внаслідок гідростатичного тиску з боку пуансонів і бічних стінок напівматриць заготівка піддається всебічному стисканню, що уможливлює одержання у закритій матриці об'ємних кулястих заготівок з ультрадрібнозернистою наноструктурою за мінімальних циклів обробки.

Ключові слова: метод ліній ковзання, метод кінцевих елементів, напружений стан, закрита матриця, стискувальні напруження, всебічне стискання.

(Received February 28, 2021)

\section{INTRODUCTION}

There are increased requirements for physical and mechanical properties of bulk workpieces made of aluminium alloys, which are used for the production of parts operating under high cyclic bending and contact loads, impact and wear and used in mechanical engineering, aerospace, transport equipment, as well as for the production of workpieces with optimal electrical and thermal properties for heat power engineering and electrical engineering, the main of them are the optimal combination of mechanical properties-plasticity and strength, the required level of heat resistance, durability, fatigue strength, hardness, wear resistance, corrosion resistance, electrical resistance. Currently, to obtain bulk aluminium workpieces for various industries that meet the above requirements for physical and mechanical properties, three methods are mainly used: a) metallurgical methodsmethods of modifying the chemical composition of the material by alloying with various modifiers [1-3]; b) heating methods-methods of heat treatment and thermomechanical treatment [4, 5]; c) methods of severe plastic deformation (SPD) [6-10]. The first two methods are considered traditional and have a number of problems and drawbacks: a) due to the use of often expensive alloying additives (for example, rare earth elements such as scandium, cerium, etc.), as well as due to the complication of requirements for casting and carrying out subsequent heat and thermomechanical processing increases the cost of the resulting blanks; b) an increase in mechanical properties is usually only $15-25 \%$, while an increase in the content of modifiers or alloying additions leads to a decrease in corrosion and fatigue properties. The use of SPD methods allows solving these problems and eliminating drawbacks. This is the reason for the rapid growth of quantitative and qualitative indicators of publications and research in recent years in the field of SPD in the world. An important factor is that the most de- 
veloped and developing countries, such as the USA, China, Japan, Russia, Germany, and India, are leading in the ranking of countries in terms of the total number of publications in the field of SPD [10].

SPD methods are innovative technologies for processing materials by pressure, used to obtain bulk ultrafine-grained (UFG) and nanostructured (NS) materials with unique properties by strong grinding of grains to UFG (grain size less than $1000 \mathrm{~nm}$ ) or to nanometric (grain size less than $100 \mathrm{~nm}$ ) range [6].

As a rule, SPD is accompanied by a complex stress-strain state (SSS) and high shear deformations. These phenomena, in turn, lead to the fact that structural defects (dislocations), being compressed, acquire a high density, the defects begin to liquidate or decrease. The structure of the metal is highly fragmented and misoriented due to intense shear deformations. The material obtained is also largely non-porous [6].

When choosing the SPD method, it is necessary to take into account that in many methods for obtaining aluminium workpieces with UFG or NS, or the workpieces obtained after the implementation of the method have limited small dimensions, such as in the high-pressure torsion method [11-14], or plastic deformation is accompanied by numerous cycles, as in the equal-channel angular pressing [15-17] and multi axial forging $[18,19]$. All these processes are focused on creating high pressures in the zone of plastic deformation [6].

The foregoing first problem makes it impossible to obtain workpieces with medium or large dimensions, being limited to obtaining discshaped workpieces of small thickness, which makes it difficult to use them on an industrial scale. The second problem makes the process time consuming and complicated. For example, multi axial forging $[18,19]$, is accompanied by multiple tilting of the workpiece around its axes until the UFG and/or NS workpiece is obtained, which significantly complicates the process, i.e. the process becomes very time consuming. Therefore, in order to obtain an UFG structure and/or NS with a small number of deformation cycles and study the microstructure of a metal under triaxial compression of a workpiece, a closed die is developed [20], experimental studies were carried out, and the stress-strain state is assessed (determination of hydrostatic stress).

\section{EXPERIMENTAL/THEORETICAL DETAILS}

\subsection{Closed Die Design and Experimental Procedure}

A closed die for triaxial compression of workpieces (balls) consists of the following main and auxiliary units and elements (Fig. 1, a): 1outer container, 2-spherical half-dies, 3-central and side punches, 4-fasteners, 5-backing ring. A cylindrical sample with a diameter of $50 \mathrm{~mm}$ and a length of $100 \mathrm{~mm}$ made of 6063 aluminium alloy is used as 
a workpiece, the yield stress of which, depending on the state, is in the range of 100-108 $\mathrm{MPa}$.

Comprehensive compression is carried out as follows. The original workpiece 6 of a cylindrical shape, the volume of which is equal to the volume of the deformed ball, is installed in the lower half-die 2 as shown in Fig. 1, a. Deformation is carried out in a cold state at room temperature. Under the pressure of the upper crossbar of the hydraulic press, the upper spherical half-die together with the central punch begins to move downward, deforming the workpiece until the cavity of the die is filled with metal (the first deformation cycle). At this point, a small surplus of metal begins to flow into the hole of the die, where the side punches are installed, pushing it back (Fig. 1, b). After filling the cavity of the die, the closed die is tilted by $90^{\circ}$ and the displaced metal processes are deformed by the side punches in the opposite direction, creating an increased hydrostatic stress in the cavity of the closed die (the second cycle of deformation). It should be noted that the objec-

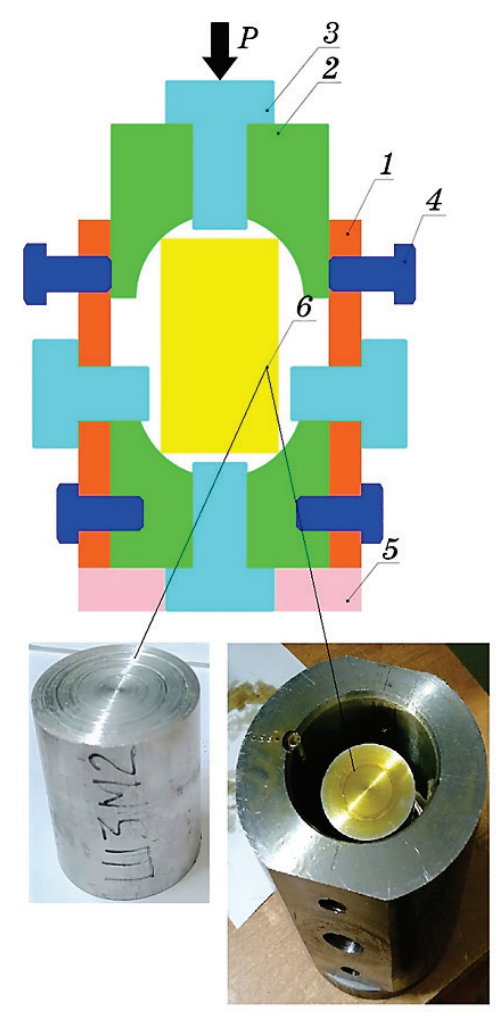

$a$

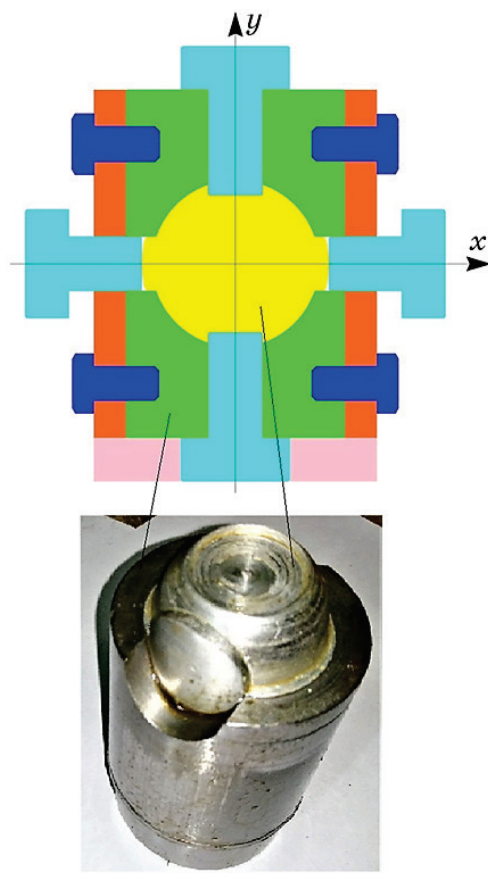

$b$

Fig. 1. The initial position of the closed die with the workpiece installed in the cavity $(a)$ and the position after the first deformation cycle $(b)$. 
tive of the experiment is not to obtain balls with appendages or depressions, but to create an increased hydrostatic stress in the die cavity from all its sides and to study changes in the metal microstructure. It is known that the formation of UFG or NS is influenced by compressive stresses or hydrostatic stress, the values of which are to be determined. In this case, the main task is to establish the number of cycles, which should be as minimal as possible. In this case, two cycles are required: deformation of the workpiece by the upper spherical half-die together with the central punch and side punches of the displaced metal in the opposite direction.

As a result of the experiment, after two cycles of deformation, spherical specimens are obtained (Fig. 1, $b$ ).

Steel billets are previously deformed in the proposed die [20]. At this stage, the die will be used in combination with a rolling mill and a special die previously developed by the authors [25].

\subsection{Theoretical and Computer Mathematical Analysis of the Stress State}

To analyze the SSS of aluminium alloy 6063 , a computer simulation of the process of triaxial compression in a closed die cavity is carried out in the DEFORM-3D modelling system (finite element method), and the slip-line field method is also used [21-24].

To analyze the evolution of metal flow and SSS by computer modelling, coordinate grids are applied to the axial section of the original cylindrical workpiece made of 6063 aluminium alloy (Fig. 2).

From the distortion of the coordinate grid, it can be seen that after the first cycle, the movement or flow of the metal occurs towards the

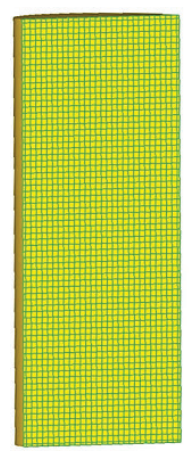

$a$

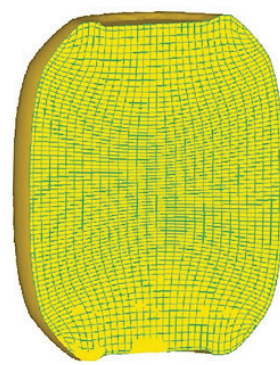

$b$

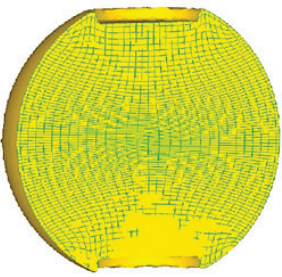

$c$

Fig. 2. Evolution of metal flow during deformation: initial state of the workpiece $(a)$; in the middle of the first deformation cycle $(b)$; at the end of the first deformation cycle $(c)$. 
side punches according to the law of least resistance. This means that at approximately the middle of the first deformation cycle, insignificant tensile stresses with a maximum value of $32.4 \mathrm{MPa}$ are observed in the sides of the workpiece (Fig. 3,a), and compressive stresses are observed in the remaining zones of the half-die workpiece, since in the middle of the first deformation cycle the workpiece is subjected to triaxial compression from the side of the central upper and lower punches, as well as semi-dies. In particular, according to Fig. 3, $a$, it can be seen that in the middle of the first deformation cycle in the cruciform zone of the workpiece (in the zone under the upper and above the lower central punches, as well as in the central zone of the workpiece), compressive stresses are observed with a value from -88.2 MPa to $-149 \mathrm{MPa}$, and in the zones adjacent to the spherical plane, compressive stresses are observed with a value from $-149 \mathrm{MPa}$ to $-269 \mathrm{MPa}$.

Towards the end of the first cycle of deformation (Fig. 3, $b$ ), the stress state is characterized by a triaxial compression. In the cruciform zone, significant compressive stresses are observed with a value from -403 $\mathrm{MPa}$ to $-533 \mathrm{MPa}$, and in the remaining zones, compressive stresses with a value from $-273 \mathrm{MPa}$ to $-403 \mathrm{MPa}$. The smallest values of compressive stresses are observed in the zones of the side punches. To eliminate it and create an even better stress state, the second cycle is implemented, i.e. deformation by side punches to a certain penetration depth.

To analyze the stress state and determine the mean stress or hydrostatic stress is determined by the slip-line field method [21-24]. The construction of the field of slip lines begins from the side of the metal exit from the die cavity into the hole of the side punch, i.e. from section $A$ and $B$, where the slip lines should go out at an angle of $45^{\circ}$ or $\pi / 4$ radians. The specified surface can be considered in this case free from the load and the sliding lines should protrude at an angle of $45^{\circ}$ (Fig. 4).

Further, observing the property of orthogonality of the grid of slip

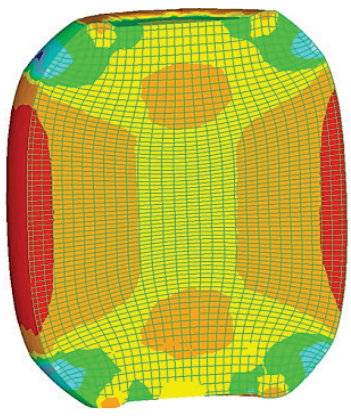

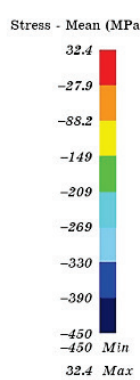

32.4 Max

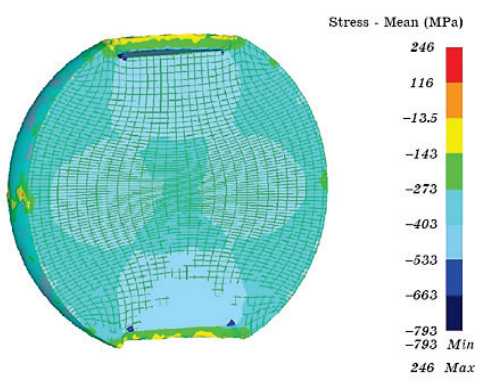

$b$

Fig. 3. Stress state of 6063 aluminium alloy: in the middle of the first cycle of deformation $(a)$; at the end of the first deformation cycle $(b)$. 


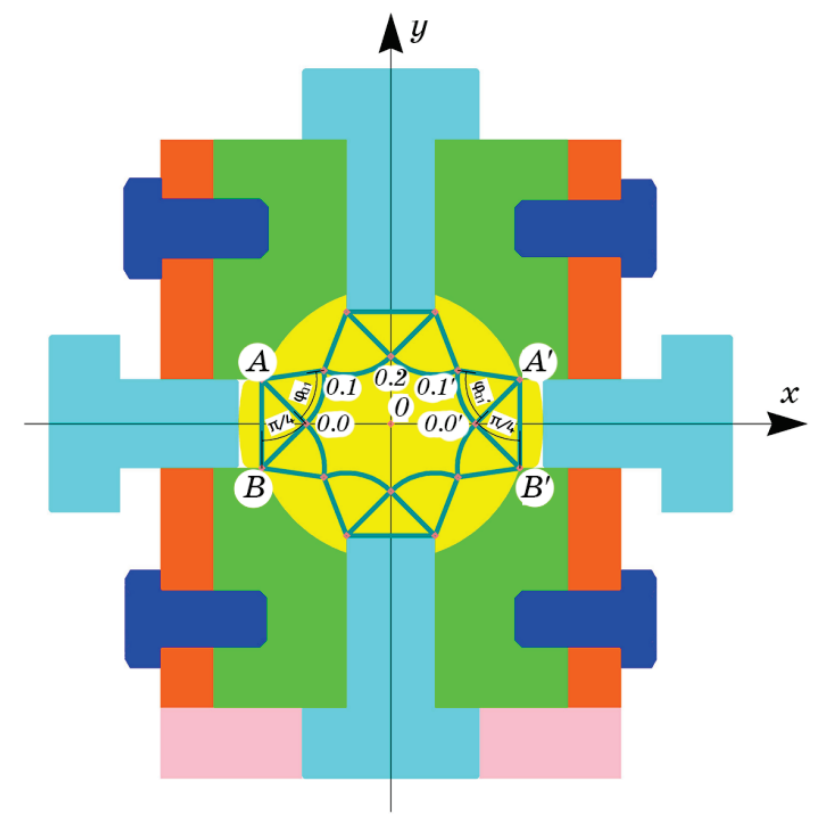

Fig. 4. Field of slip lines in the zone of plastic deformation.

lines, it is constructed up to nodal points 0.1 and 0.2 , where the grid of slip lines is connected from the side of the central and side punches. It can be seen from the constructed grid of slip lines that the central cruciform zone of the workpiece is fully subjected to triaxial compression both from the side of the central punches and from the side of the side punches and walls of the semi-die.

\subsection{The Mechanism of Grain Size Refinement and Material Strengthening}

Triaxial compression and the influence of grain-dislocation factors contribute to significant refinement of the grain structure and strengthening of the material.

The grain size refinement is due to grain-boundary strengthening or Hall-Petch strengthening. The mechanism of this strengthening can be explained as follows. Before plastic deformation, there are dislocations in a certain amount in the grains of the material. During plastic deformation, these dislocations and newly formed dislocations (for example, dislocations created by Frank-Read sources [26]) will move through the crystalline lattices of the grains to the grain boundaries, where these boundaries and their disorder impede the movement of dislocations and they accumulate along the grain boundaries. With an in- 
crease in the deformation force (stresses), the accumulated dislocations trigger the grain-boundary diffusion mechanism and create a stress-strain state in neighbouring grains, which in turn deforms the grains. The more grains are formed in a polycrystalline material, the more barriers that restrict the movement of dislocations, which means that the material is strengthened and its yield strength increases. Thus, it can be assumed that there is a relationship between grain size and yield strength (stress). This relationship can be demonstrated by the well-known Hall-Petch relationship:

$$
\sigma_{y}=\sigma_{0}+\frac{k_{y}}{\sqrt{d}},
$$

where $\sigma_{y}$ is the yield stress; $\sigma_{0}$ is the frictional stress, which is necessary for the movement (sliding) of dislocations; $k_{y}$ is the materialspecific strengthening factor, also called the Hall-Petch factor; $d$ is the mean grain size.

It is important to note that recent experimental studies of nanocrystalline materials, including aluminium alloys [27, 28], have shown that the Hall-Petch relationship is not always effective; upon reaching a certain critical grain size (on the order of several tens of nanometres), no further increase in the yield stress is observed: the yield stress remains constant or decreases (the material softens) even if the grain size decreases. This paradox is called the inverse Hall-Petch effect. Despite the fact that recently a lot of experimental and research works devoted to this effect in nanocrystalline materials have been carried out, the gist and mechanisms of this phenomenon remain insufficiently studied and require further, more in-depth studies.

Based on the above, for a mathematical assessment of the effect of dislocation hardening on the strength of the material, the authors of the study suggest using the following equation:

$$
\sigma_{d}=M \alpha G b \sqrt{\rho},
$$

where $\sigma_{d}$ is the dislocation strengthening effect; $M$ is the Taylor factor (crystallographic characteristic of material strength); $\alpha$ is a constant; $G$ is the shear modulus of the material; $b$ is the magnitude of Burgers vector; $\rho$ is the dislocation density.

\section{RESULTS AND DISCUSSION}

The mean stress at the nodal point 0.0 is determined from the conditions that in the section $A$ and $B$, i.e. at the exit of the metal from the hole of the die: 


$$
\begin{gathered}
\sigma_{y_{0.0}}=-\sigma_{S}, \\
\sigma_{x_{0.0}}=0,
\end{gathered}
$$

since the lateral surface of the offshoot (emerging into the hole of the metal) is free of load. Then the mean stress at point 0.0 will be equal to:

$$
\sigma_{0.0}=-0.5 \sigma_{S}^{*},
$$

where $\sigma_{S}^{*}$ is the strain or deformation resistance, the value of which is taken depending on the value of the yield stress of 6063 aluminium alloy, i.e. $\sigma_{S}=100-108 \mathrm{MPa}$, and the coefficients that take into account the strain hardening of the metal $n_{\varepsilon}$, the stress state of the metal $n_{\sigma}$, Lode coefficient ( $\beta=1.15$ ), taking into account the conditions of plane deformation. Hence, after adopting the corresponding values of the coefficients, the strain resistance is

$$
\begin{gathered}
\sigma_{S}^{*}=\sigma_{S} n_{\varepsilon} n_{\sigma} \beta, \\
\sigma_{S}^{*}=-174.5 \mathrm{MPa} .
\end{gathered}
$$

Further, using the well-known Hencky equations [21-24], the mean stress (hydrostatic stress) is determined at the nodal point 0.1 , and then at the point 0.2:

$$
\sigma_{0.1}=\sigma_{0.0}-\sigma_{S}^{*}\left(\Delta \theta_{0.1}\right),
$$

where $\Delta \theta_{0.1}$ is the angle of rotation of the slip line at the transition from the nodal point 0.0 to the nodal point 0.1 . Hence, the value of the mean stress at the nodal point 0.1 will be equal to:

$$
\sigma_{0.1}=-\sigma_{S}^{*}\left(0.5+\Delta \theta_{0.1}\right)=-248.66 \mathrm{MPa} .
$$

By analogy, the mean stress at point 0.2 is determined:

$$
\sigma_{0.2}=\sigma_{0.1}-\sigma_{S}^{*}\left(\Delta \theta_{0.2}\right)=-410 \mathrm{MPa},
$$

where $\Delta \theta_{0.2}$-the angle of rotation of the slip line when passing from the nodal point 0.1 to the nodal point 0.2 .

The obtained values are in good agreement with the values obtained by computer simulation (Fig. 3, $b$ ), where the stress values from the contact surface to the central zones of the workpiece are in the range of -143 to $-403 \mathrm{MPa}$, on mean $-273 \mathrm{MPa}$. Approximately the same values are obtained in the above calculation by the calculation method of slip lines, where the values of the compressive mean, hydrostatic stresses are in the range of -248.66 to $-410 \mathrm{MPa}$. The slight difference in the 
obtained values can be explained by the difference in the edge or boundary conditions adopted in these two methods. Therefore, with a certain error, it is possible to accept the fields of the slip lines and the fields obtained by computer simulation to be identical.

\section{CONCLUSION}

The stress state of the workpieces (balls) under the triaxial compression in a closed die has been evaluated. Analysis of the results obtained by the slip-line field method, mathematical computer modelling and experimental data shows that maximum compressive mean (hydrostatic) stresses act in the volume of the workpiece, contributing to the production of workpieces with UFG and/or NS with minimal processing cycles. The resulting workpieces can be used further in the production of bar, long, bulk products for mechanical engineering, instrument making, aerospace, transport technology, electrical engineering or other industries.

\section{REFERENCES}

1. E. B. Moustafa and A. O. Mosleh, J. Alloys. Compd., 823: 153745 (2020).

2. E. Aghaie, J. Stroh, D. Sediako, A. Rashidi, and A. S. Milani, Mater. Sci. Eng. A, 793: 139899 (2020).

3. Y. Chen, S. Zhang, H. Song, M. Cheng, H. Li, and J. Liu, Mater. Des., 91: 314 (2016).

4. J. Ren, Z. Chen, J. Peng, W. Ma, and S. P. Ringer, J. Alloys. Compd., 764: 679 (2018).

5. M. Li, P. Hu, Y. Zhang, and Y. Chang, J. Nucl. Mater., 543: 152482 (2021).

6. R. Z. Valiev, A. P. Zhilyaev, and T. G. Langdon, Bulk Nanostructured Materials: Fundamentals and Applications (Hoboken: John Wiley \& Sons, Inc.: 2014).

7. I. Sabirov, N. A. Enikeev, M. Yu. Murashkin, and R. Z. Valiev, Bulk Nanostructured Materials with Multifunctional Properties

(Cham: SpringerBriefs in Materials: 2015).

8. G. Faraji, H. S. Kim, and H. T. Kashi, Severe Plastic Deformation: Methods, Processing and Properties (Amsterdam: Elsevier Inc.: 2018).

9. R. N. Harsha, V. Mithun Kulkarni, and B. Satish Babu, Mater. Today. Proc., 5, No. 10: 22340 (2018).

10. E. Bagherpour, N. Pardis, M. Reihanian, and R. Ebrahimi, Int. J.Adv. Manuf. Tech., 100: 1647 (2019).

11. Y. Liu, H. Wang, C. Lu, and A. K. Tieu, Mater. Lett., 277: 128272 (2020).

12. Y. Liu, C. Lu, H. Wang, A.K. Tieu, and B. Liu, J.Mater. Res. Technol., 9, No. 3: 6642 (2020).

13. U. Okeke, H. Yilmazer, S. Sato, and C. J. Boehlert, Mater. Sci. Eng. A, 760: 195 (2019).

14. M. Khajouei-Nezhad, M. H. Paydar, R. Ebrahimi, P. Jenei, P. Nagy, and 
J. Gubicza, Mater. Sci. Eng. A, 682: 501 (2017).

15. P. Vishnu, R. Raj Mohan, E. K. Sangeethaa, S. Raghuraman, and

R. Venkatraman, Mater. Today. Proc., 21, No. 1: 212 (2020).

16. M. Howeyze, H. Arabi, A. R. Eivani, and H. R. Jafarian, Mater. Sci. Eng. A, 720: 160 (2018).

17. A. Esmaeili, M. H. Shaeri, M. T. Noghani, and A. Razaghian, J.Alloys Compd., 757: 324 (2018).

18. M. Montazeri-Pour, M. H. Parsa, H. R. Jafarian, and S. Taieban, Mater. Sci. Eng. A, 639: 705 (2015).

19. S. S. Sajjan, M. V. Kulkarni, S. Ramesh, P. C. Sharath, V. Kumar, and S. Rajole, Mater. Today Proc., 24, No. 2: 212 (2020).

20. M. Abishkenov, Zh. Ashkeyev, S. Mashekov, G. Akhmetova, and I. Volokitina, Metalurgija, 59, No. 4: 559 (2020).

21. W. F. Hosford, Fundamentals of Engineering Plasticity (New York: Cambridge University Press: 2013).

22. R. Hill, The Mathematical Theory of Plasticity (Oxford: Oxford University Press: 1998).

23. M.-H. Yu, G.-W. Ma, H.-F. Qiang, and Y.-Q. Zhang, Generalized Plasticity (Berlin-Heidelberg: Springer: 2006).

24. D. W. A. Rees, Basic Engineering Plasticity: An Introduction with Engineering and Manufacturing Applications (Oxford: Butterworth-Heinemann: 2006).

25. Zh. Ashkeyev, M. Abishkenov, S. Mashekov, and A. Kawałek, Eng. Sol. Mech., 9, No. 2: 161 (2021).

26. F. C. Frank, Proc. R. Soc. A, 371: 136 (1980).

27. K. Maung, J. C. Earthman, and F. A. Mohamed, Acta Mater., 60, No. 16: 5850 (2012).

28. Y. Ito, K. Edalati, and Z. Horita, Mater. Sci.Eng. A, 679: 428 (2017). 